\title{
MASSIVE PULMONARY EMBOLISM OF CEREBELLAR TISSUE IN A NEWBORN
}

\author{
BY \\ HANNA TRYFUS* \\ From the Department of Pathology, Kaplan Hospital, Rehovoth, Israel
}

(RECEIVED FOR PUBLICATION SEPTEMBER 13, 1962)

Emboli consisting of brain tissue fragments in the pulmonary circulation have been described in adults and children as an unusual complication of head injuries with lacerations of the brain (Ceelen, 1931; Krakower, 1936; McMillan, 1956; Oppenheimer, 1954). Foci of brain tissue have also been found growing in the lungs of newborn babies with severe malformations of the central nervous system, and it has been suggested that these were the result of embolization after severe prenatal trauma to the head (Gruenwald, 1941; Potter and Young, 1942). The occurrence of such emboli as a result of birth trauma, however, seems to be rare, only one such case having apparently been recorded to date (Gardiner, 1956). The present paper reports on similar findings in an infant dying 10 minutes after birth.

\section{Case Report}

The infant was born to a 34-year-old multipara, who had one normal birth and one previous miscarriage which resulted in the delivery of a dead premature foetus. The child was delivered as a footling by the Veit Smellie manoeuvre five hours after the onset of labour, which started two months before the end of a normal pregnancy. Ten minutes after birth the baby died of severe asphyxia and all attempts at resuscitation were unsuccessful. Its weight was $1,800 \mathrm{~g}$. and crown-heel length was $42 \mathrm{~cm}$.

At autopsy no external malformations were found. The lungs were unexpanded. The brain was soft and friable, but grossly normal except for some small haemorrhages in the cerebellar white matter. There were several superficial tears in both leaves of the tentorium and about $20 \mathrm{ml}$. fresh blood in the subtentorial space. Other internal organs, except the lungs, showed no gross or microscopic changes.

Histological examination of the lungs showed that

*Dr. Hanna Tryfus died on February 13, 1963. Requests for reprints should be sent to Dr. E. Liban, Department of Pathology, Kaplan Hospital, Rehovoth, Israel. almost all medium-sized and some small branches of the pulmonary artery were occluded by fragments of cerebellar tissue (Fig. 1). Many of these fragments showed the typical pattern of infantile cerebellar cortex, with an outer zone consisting of densely packed cells with dark round nuclei (the external granular layer), and an inner eosinophilic fibrillar zone (the molecular layer), but without any Purkinje cells (Fig. 2). Other emboli consisted of white matter with glial nuclei and some capillaries. All these fragments were well preserved. No blood clots or other embolic material were found.

Histological examination of the brain showed some haemorrhages in the cerebellar white matter near the dentate nucleus. Small pial veins on the posterior surface of the medulla oblongata contained emboli of cerebellar cortical tissue and white matter (Fig. 3) and similar emboli were found in veins draining the choroid plexus of the lateral ventricles. It was not possible to identify the exact place from which the pieces of cerebellum had become detached, the tissue being too soft and friable for adequate examination even after formalin fixation.

\section{Discussion}

Lacerations of the tentorium and bleeding into the subtentorial space are not infrequent in cases of footling presentation. In the present case no tears in sinuses or veins were found at gross examination, but the finding of emboli in the cerebral veins can best be explained by assuming the occurrence of a tear in the straight sinus which runs between the two leaves of the tentorium and could allow penetration of cerebellar tissue into the circulation. The penetration of lacerated brain tissue into veins could have been caused by different and intermittent pressures acting on the foetal head during delivery; these are known to affect the blood flow especially in the vein of Galen (Schwartz, 1961). This vein drains the blood from the choroid plexus which flows into the straight sinus. Since emboli of cerebellar tissue were found in the veins of the choroid plexus and of the posterior surface 


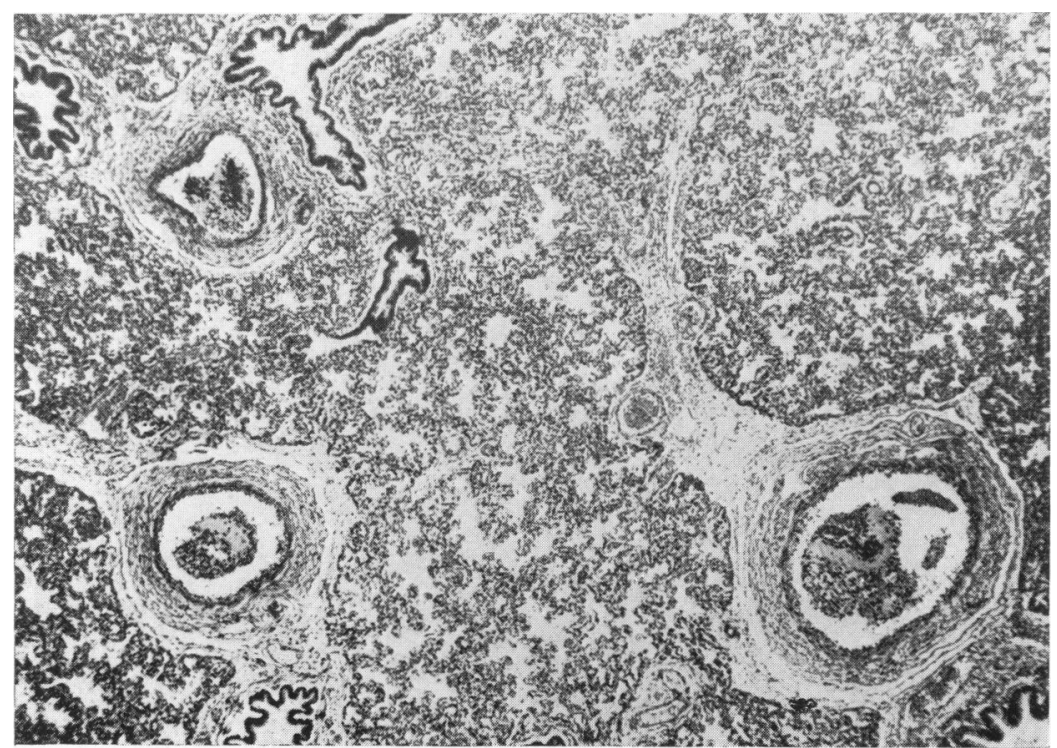

FIG. 1.-Pulmonary arteries containing fragments of cerebellar tissue.

(H. and E. $\times$ 45.)

of the medulla oblongata, it seems reasonable to assume a reversal of blood flow in the venous system around the cerebellum at the moment of injury caused probably by a temporary block in the flow through the great vein of Galen (Schwartz, 1961).
The tissue fragments are then carried via the blood stream to the right side of the heart and finally lodge in the pulmonary vessels causing anoxia and death.

In the absence of any signs of haemorrhage or

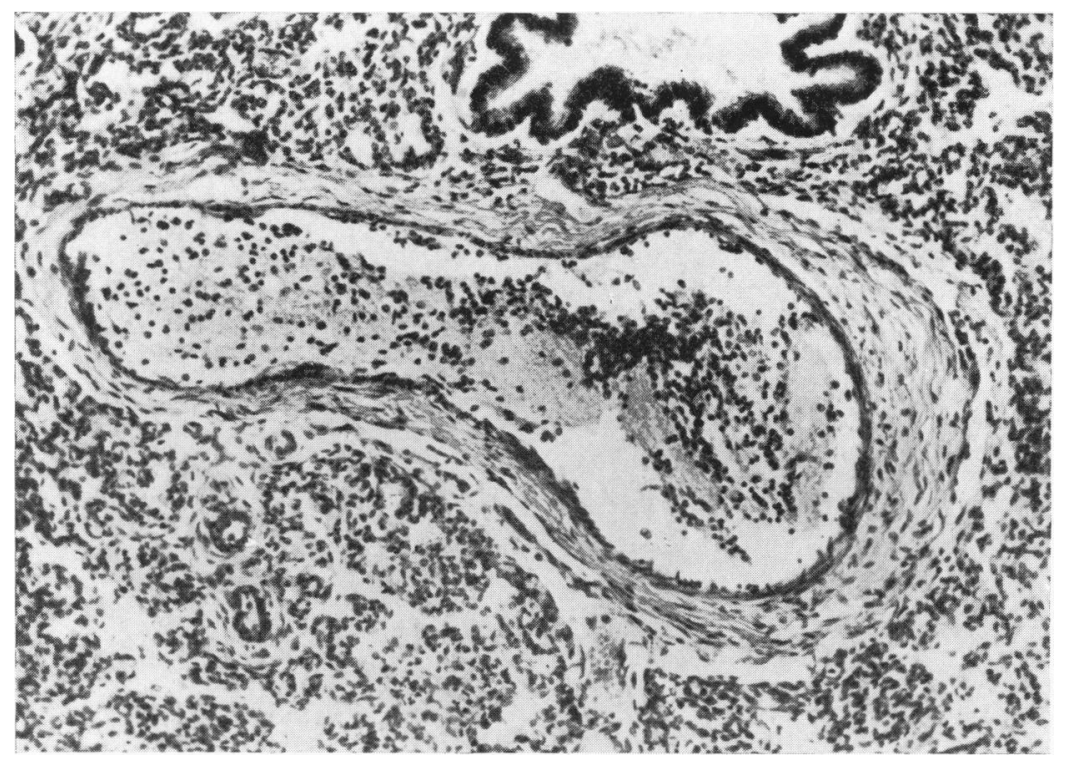

FIG. 2.-Infantile cerebellar cortical tissue in a small pulmonary artery. (H. and $\mathrm{E} \times 150$.) 


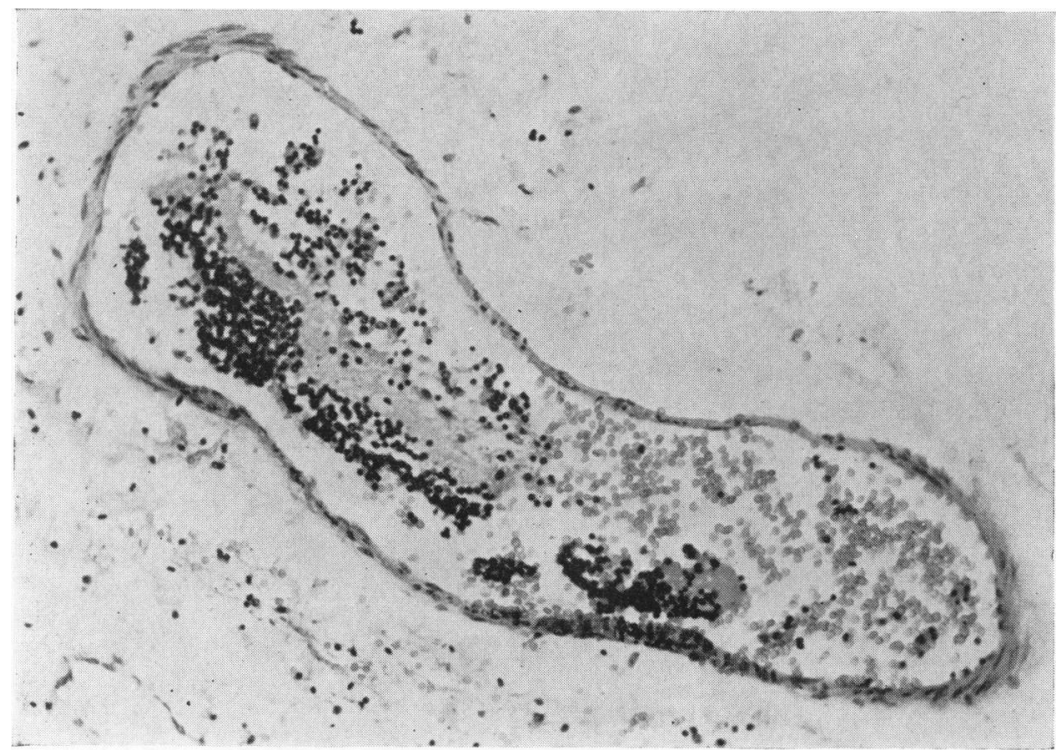

Fig. 3.-Cerebellar cortical tissue in a small pial vein of the medulla oblongata. (H. and E. $\times$ 150.)

inflammation in the cerebellar subcortical layer, the nature of the injury causing disruption of the tissue remains a matter of speculation. In the newborn, and especially in the premature one, separation of the cerebellar cortex from the deeper layers is commonly found in routine histological preparations and is usually regarded as an artefact due to fixation. The strips of tissue found in the pulmonary vessels by Gardiner (1956) and by us in the present case correspond in width to the layers of cortex 'artefactually' separated from the remainder of the tissue in routine sections. It is possible, therefore, that this artefact is based on a zone of greater fragility along the line of Purkinje cells, between the outer layers of the cortex and the core of the cerebellar folia. The fragments of white matter found in some vessels might have been derived from the region near the dentate nucleus, where haemorrhages were observed.

\section{Summary}

A case of cerebellar embolism as a result of birth trauma is reported. The haemodynamics and possible mechanism of this unusual lesion is discussed.

I should like to thank Dr. Z. Dim for the clinical details, Dr. E. Liban for his helpful suggestions, and Mrs. R. Scharfberg for the photographs.

\section{REFERENCES}

Ceelen, W. (1931). Verschleppung von Hirngewebe. In F. HenkeO. Lubarsch's Handbuch der speziellen pathologischen Anatomie und Histologie, Vol. 3, pt. 3, p. 107. Springer, Berlin.

Gardiner, W. R. (1956). Massive pulmonary embolization of cerebellar cortical tissue. An unusual fetal birth injury. Stanf. med. Bull., 14, 226.

Gruenwald, P.(1941). Emboli of brain tissue in fetal lungs. Amer. J. Path. 17, 879 .

Krakower, C. (1936). Pulmonary embolus containing cerebral

Krakower, Arch. Path., 22, 113.
tissue. A
McMillan, J. B. (1956). Emboli of cerebral tissue in the lungs following severe head injury. Amer. J. Path., 32, 405.

Oppenheimer, E. H. (1954). Massive pulmonary embolization by cerebral cortical tissue. Bull. Johns Hopk. Hosp., 94, 86.

Potter, E. L. and Young, R. L. (1942). Heterotopic brain tissue in the lungs of two anencephalic monsters. Arch. Path., 34, 1009.

Schwartz, P. (1961). Birth Injuries of the Newborn, p. 26. Karger, New York and Basle. 